\title{
FACTORS INFLUENCING LIGHT SCATTERING IN THE EYE
}

\author{
G. Ikaunieks, M. Ozolinsh, A. Stepanovs, \\ V. Lejiete, N. Reva
}

\author{
University of Latvia, Department of Optometry and Vision Science
}

\begin{abstract}
Our vision in the twilight or dark is strongly affected by the intraocular light scattering (straylight). Of especial importance is to assess this phenomenon in view of the night driving. The authors have studied the spectral dependence of retinal straylight and estimated the possibility to reduce it with yellow filters and small apertures. For the measurements the direct compensation flicker method was used. The results show that this spectral dependence is close to Rayleigh's scattering $\left(\propto \lambda^{-4}\right)$. As could be expected from the known data, the yellow filter should reduce retinal straylight, especially for blue light. However, in the experiments this scattering was not removed with such a filter but instead slightly increased. The optical apertures reduced light scattering in the eye, especially for red color.

Key words: intraocular light scattering (straylight), spectral dependence, color filters, aperture.
\end{abstract}

\section{INTRODUCTION}

One of the factors that can influence the optical visual quality is intraocular light scattering (straylight). Such scattering reduces the luminance contrast of a perceived image [1]. Straylight causes the so-called disability glare (impairing the vision of objects without necessarily causing discomfort [2, 3]). Typically, such a situation occurs during night driving when there are oncoming car headlamps somewhere in a driver's visual field. The main source for intraocular light scattering in a healthy eye is light scattering from cornea and lens. An additional factor is the amount of pigmentation in the eye, which influences the spectral dependence of straylight. If this amount is small (blue eyes), the incoming light more reflects from the retina and more light (especially red) penetrates through non-optical parts of the eye - sclera and iris [4]. For young subjects the spectral dependence of straylight for short (blue) and medium (green) wavelengths is close to Rayleigh's scattering $\left(\propto \lambda^{-4}\right)$ [5]. Straylight for long wavelengths (red) is greater than could be expected from the Rayleigh law and, as mentioned above, the greatest effect is for blue eyes and the smallest - for brown ones.

Other researchers [6] showed that a yellow filter can strengthen visual functions, especially in the mesopic conditions. They mentioned many mechanisms of this phenomenon. In particular, they suggested that a yellow filter reduces light scattering in the eye, since it cuts off blue light, which is scattered more than other wavelengths $[6,7]$. One of the purposes of our study was to verify this suggestion. Another purpose was to evaluate the amount of light which penetrates through nonoptical parts of the eye. To do this, we put a small aperture $(5 \mathrm{~mm})$ in front of the eye. Such evaluation could be useful for clinical examination of the patients with an increased straylight level. It was also important to find out the cause of increase 
in the straylight - whether it is due to changes in the optics of an eye or due to the light penetration through its walls owing to low pigmentation [8].

\section{METHOD}

For the intraocular light scattering (straylight) measurements the direct compensation method of van den Berg was used (for its description see, e.g. [9]). Briefly, an annulus flickering symmetrically to the gaze direction with a frequency of $\sim 8 \mathrm{~Hz}$ is shown to the subject (person under test) (Fig. 1).

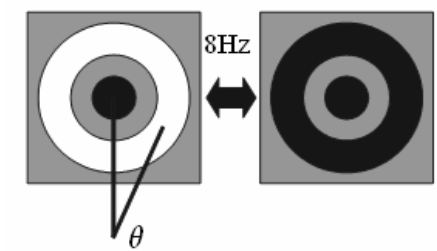

Fig. 1. Test stimulus in the direct compensation method.

Due to the light scattering in the eye, the subject perceives flicker also in the annulus center (test field). If counter-phase modulating light is shown in the test field with the same frequency, it is possible to compensate the straylight coming from the annulus, and flickering in the center disappears. The subject's task during measurements is to stare fixedly at the test stimulus and to find the level of the testfield luminance that compensates flickering in the center of annulus. The retinal straylight can be calculated from the equation [1]:

$$
s=\frac{\theta^{2} L}{E},
$$

where $L$ is the luminance of the test stimulus;

$E$ is the illuminance at the pupil plane caused by the straylight source;

$\theta$ is the angular distance (degrees) of the glare source from the fixation point.

The stimulus was made from three color (red, green, blue) light-emitting diodes (LEDs). The spectral characteristics of corresponding bands are shown for each LED in Fig. 2.

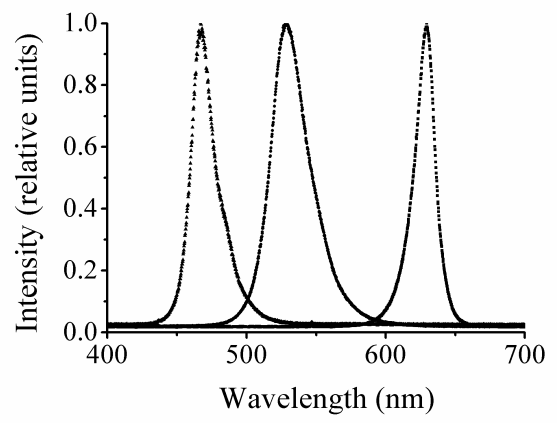

Fig. 2. Spectral parameters of straylight sources (LEDs) in the direct compensation method. 
The diodes were arranged around a circle having a radius subtending 5.5 degrees at the subject's eye. In the middle of this set of LEDs a circular $14 \mathrm{~mm}$ thick plexiglass plate was attached. Diodes were put around the sides of this plate. When LEDs on the disc were illuminated, it appeared bright to an observer. The disc size was 1.5 degrees, and the distance from stimulus was $60 \mathrm{~cm}$. The LED lamps in the outer annulus flickered at $8 \mathrm{~Hz}$, and a subject's task was to adjust the counter-phase luminance flicker in the center to produce the least perceived flicker. The luminance of the central plexiglass stimulus was changed using a power supply with regulated output current. The luminance and illuminance values were calculated from the calibration data (Minolta CS-100 chromameter, Meterman LM631 light meter).

With the LED stimulus three sets of experiments were run. The first one (with nine subjects participating) was performed for red, green and blue color light to find out the spectral dependence of intraocular straylight. The second set of the experimental measurements was carried out for green and red light, with a circular aperture $(5 \mathrm{~mm}$ in diameter) placed on a trial frame, and without it; the other eye was covered (eight subjects participating). The third set of experiments was done for all three color stimuli, with and without a yellow filter in front of the eye. Light transmittance of the filter is shown in Fig. 3 (four subjects participating). The age of all subjects under test was 21-28 years.

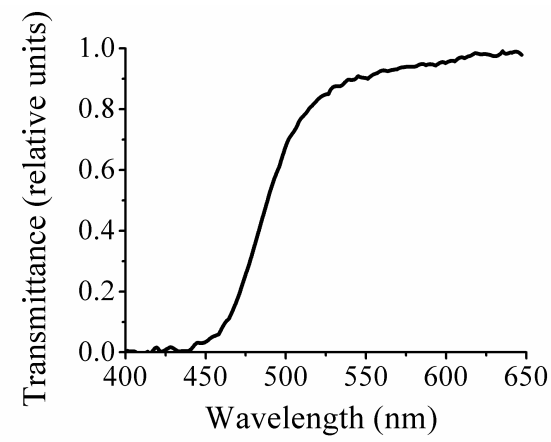

Fig. 3. Light transmittance of the yellow filter.

\section{RESULTS}

The measured values of intraocular light scattering, $s$, with red (dominant wavelength $604 \mathrm{~nm})$ green $(546 \mathrm{~nm})$ and blue $(471 \mathrm{~nm})$ stimuli are shown in Fig. 4. The results correspond to those of the previous study [5], which showed the highest straylight values for short wavelengths stimuli (blue light) and the smallest ones for green light.

Results of the second experiment with and without aperture are shown in Fig. 5. For each measurement the standard deviations are given. A circular aperture in front of the eye reduces intraocular light scattering from both light sources (red and green). As was expected, the greatest changes are for red color, since less light penetrates through the ocular wall when an aperture is used. 


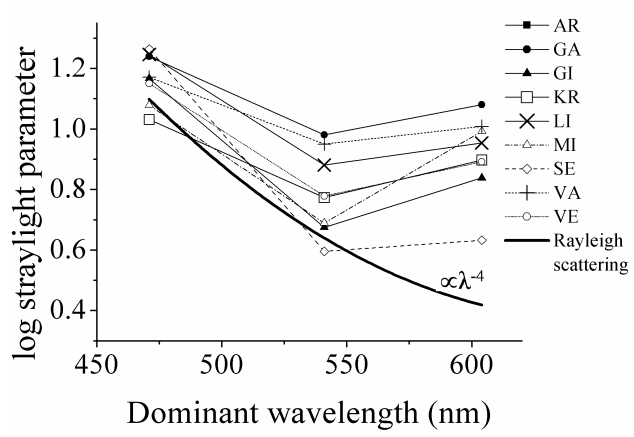

Fig. 4. Spectral dependence of straylight.

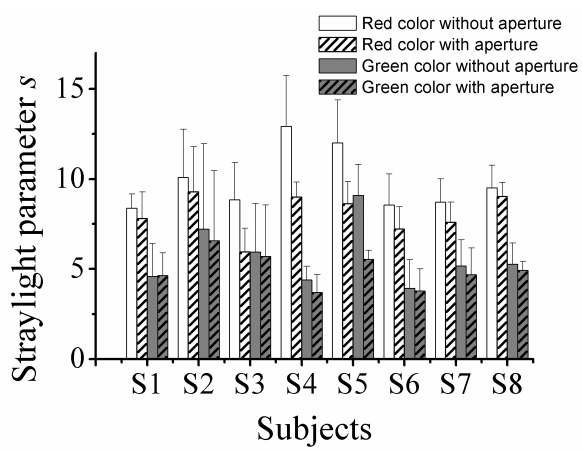

Fig. 5. Straylight values for red and green color stimuli with and without aperture.

Results of the third experimental set with and without yellow filter for one subject are shown in Fig. 6. The straylight was stronger in the measurements with yellow filter than in the normal conditions for all three colors. The same tendency was also found for others subjects.

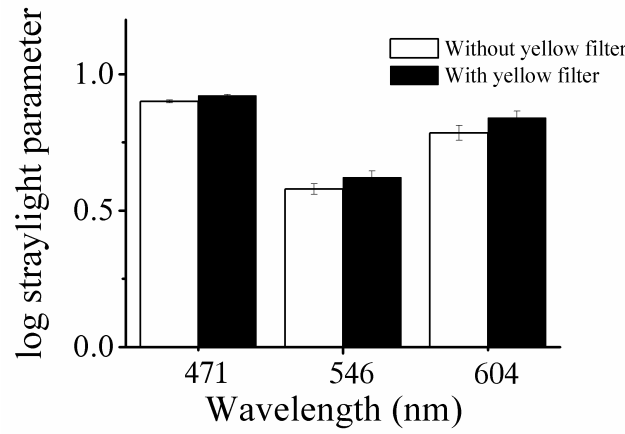

Fig. 6. Straylight values with and without yellow filter for blue $(471 \mathrm{~nm})$, green $(546 \mathrm{~nm})$ and red $(604 \mathrm{~nm})$ stimuli. Results are shown for one subject.

\section{DISCUSSION}

Straylight measurements with and without aperture have shown that it is possible to evaluate the amount of light penetrating through the non-optical part of the eye. Five subjects from 8 showed statistically smaller straylight value for 
measurements with aperture than without it for red color. For green light only one subject showed statistically different results with and without aperture.

The most surprising results were obtained in the experiment with and without yellow filter in front of the eye. We expected that yellow filter would reduce scattering for blue light; as can be seen in Figs. 2 and 3, the yellow filter removes most of the light which comes from the blue LED. However, our results show greater values of the straylight parameter with a yellow filter than without it for all subjects. For one subject additional straylight measurements were done with yellow and neutral filters for white light. In both cases straylight values were higher with the filters than without them. These results do not confirm the assumption that yellow filter removes blue light and thus reduces light scattering in the eye. In other investigations the authors argued that the improvement of contrast sensitivity in low light condition should be more related to neural mechanisms than to optical ones [7]. If a yellow filter improved optical quality of the eye, we could expect better visual acuity with yellow lenses than without them. However, studies show only a better contrast sensitivity in low light, but there are no data that a yellow filter improves the visual acuity. Concerning the effect of a yellow filter, the measurement results show that it does not reduce light scattering in the eye and even slightly raises it.

\section{CONCLUSIONS}

The main conclusions of the work are as follows.

It is possible to evaluate the amount of light which penetrates through nonoptical part of the light when a small aperture is used.

Despite the existing hypothesis that the yellow filter removes blue light thus reducing light scattering in the eye, we have shown that a yellow filter does not decrease light scattering in the eye.

\section{REFERENCES}

1. van den Berg, T.J. (1986). Importance of pathological intraocular light scatter for visual disability. Doc. Ophthalmol. 61, 327-333.

2. Aslam, T.M., Haider, D. \& Murray, I.J. (2007). Principles of disability glare measurement: an ophthalmological perspective. Acta Ophthalmol. Scand. 85, 354-360.

3. Vos, J. J. (2003). Reflections on glare. Lighting Res. Technol. 35, 163-176.

4. van den Berg, T.J., Ijspeert, J.K. \& de Waard, P.W.T. (1991). Dependence of intraocular straylight on pigmentation and light transmission through the ocular wall. Vision. Res. 31, 1361-1367.

5. Coppens, J.E., Franssen, L. \& van den Berg, T.J. (2006). Wavelength dependence of intraocular straylight. Exp. Eye. Res. 82(4), 688-692.

6. Pérez-Carrasco, M.J., Puell, C., Sánchez-Ramos, C., López-Castro, A. \& Langa, A. (2005). Effect of a yellow filter on contrast sensitivity and disability glare after laser in situ keratomileusis under mesopic and photopic conditions, J. Refr. Surgery. 21(2), $158-165$.

7. Rabin, J. \& Wiley, R. (1996). Differences in apparent contrast in yellow and white light. Ophthalmic Physiol. Opt. 16(1), 68-72.

8. Franssen, L., Coppens, J.E., \& van den Berg T.J. (2008). Grading of iris color with an extended photographic reference set. J. Optom. 1(1), 36-40.

9. Ikaunieks, G., Colomb, M. \& Ozolinsh, M. (2009). Light scattering in artificial fog and simulated with light scattering filter. Ophthalmic Physiol. Opt. 29(3), 351-356. 


\section{DAŽĀDU FAKTORU IETEKME UZ GAISMAS IZKLIEDI ACĪ}

G. Ikaunieks, M. Ozolinšs, A. Stepanovs, V. Lejiete, N. Reva

Kopsavilkums

Redzes asums ir viens no svarīgākajiem parametriem, pēc kura tiek novērtēta subjekta redzes kvalitāte dienas apstākḷ̆os. Tomēr pēc š̄ parametra ne vienmēr var izvērtēt, cik labi subjekts redzēs zema apgaismojuma apstākḷos. Viens no faktoriem, kurš var būtiski ietekmēt redzes kvalitāti krēslā vai naktī, ir gaismas izkliede acī. Gaismas izkliede uztvertā attēla kvalitāti visvairāk ietekmē tad, kad subjekta redzes laukā ir kāds spožs gaismas avots. Vadot automašīnu naktī, šādi traucējoši gaismas avoti ir pretim braucošo automašīnu lukturi. Tā kā redzes funkcijas parasti izmeklē normālos apgaismojuma apstākḷos un subjekta redzes laukā nav nekādu spožu gaismas avotu, tad redzes pārbaudes testi subjektam ar lielu gaismas izkliedi acī var uzrādīit normālas vai tikai nedaudz pazeminātas redzes funkcijas. Gaismas izkliedi acī var novērtēt ar speciālām metodēm. Šajā pētījumā tika izmantota viena no šādām metodēm - tiešā kompensācijas metode (van den Berg, 1986).

Galvenie pētījuma mērḳi bija izvērtēt gaismas izkliedes acī spektrālo atkarību un novērtēt, kā gaismas izkliedi ietekmē neliela izmēra apertūras (diametrs $5 \mathrm{~mm}$ ) novietošana acs priekšā un dzeltenie filtri. Rezultāti parādīja, ka gaismas izkliede acī vislielākā ir pie īsiem viļ̣na garumiem (zilās krāsas) un vismazākā pie vidējiem viḷ̦a garumiem (zal̦ās krāsas). Kopumā gaismas izkliede acī atkarībā no viḷna garuma mainās pēc Releja izkliedes principa $\left(\propto \lambda^{-4}\right)$, izņemot spektra sarkanajā dal̦ā. Garie gaismas viḷni acī nonāk ne tikai caur tās optiskajām dạ̦ām, bet arī caur sklēru un varavīksneni, tādejādi izkliede pie sarkanās gaismas ir lielāka nekā būtu sagaidāms no Releja izkliedes likuma. Pieliekot acij priekšā apertūru, izkliedi spektra sarkanajā dạ̧ā var samazināt, bet tik un tā izkliede pie sarkanās gaismas ir lielāka nekā pie zaļās. Rezultāti ar dzeltenajiem filtriem uzrādīja, ka filtri nesamazina gaismas izkliedi, bet nedaudz to palielina. 